This item was submitted to Loughborough's Research Repository by the author.

Items in Figshare are protected by copyright, with all rights reserved, unless otherwise indicated.

\title{
A whirlwind in occupied Holland
}

PLEASE CITE THE PUBLISHED VERSION

PUBLISHER

(C) American Society for Microbiology

VERSION

AM (Accepted Manuscript)

LICENCE

CC BY-NC-ND 4.0

REPOSITORY RECORD

Shama, Gilbert, and Gerben van der Els. 2009. "A Whirlwind in Occupied Holland". figshare. https://hdl.handle.net/2134/4088. 
This item was submitted to Loughborough's Institutional Repository (https://dspace.lboro.ac.uk/) by the author and is made available under the following Creative Commons Licence conditions.

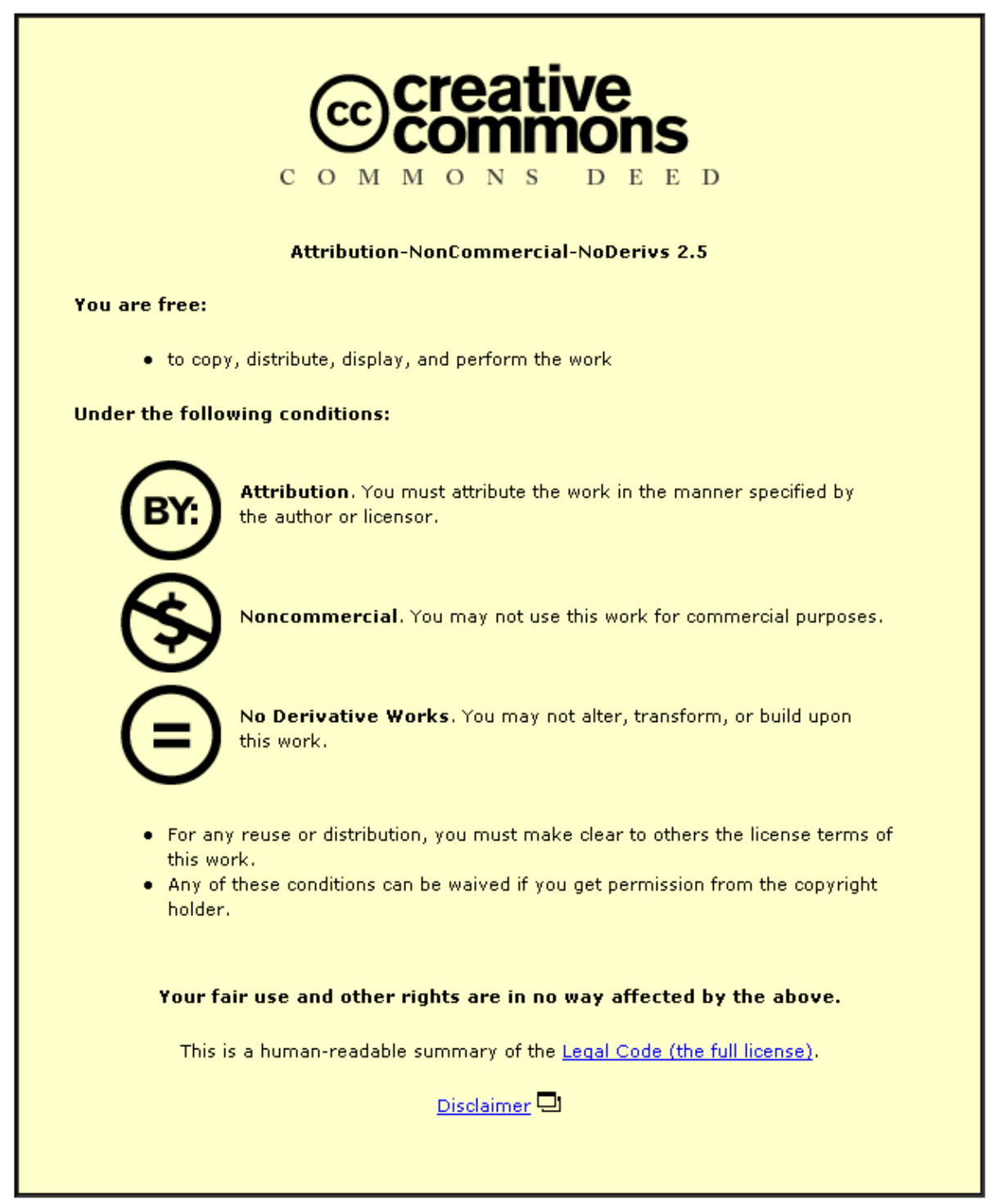

For the full text of this licence, please go to: http://creativecommons.org/licenses/by-nc-nd/2.5/ 
Publications Category 12

\section{Journal Papers - Professional Journals}

Title of Work: $\left(^{*}\right)$

A Whirlwind in Occupied Holland

Major Work: (*)

Microbe

Volume:

3

Issue:

11

Year of Publication: $\left(^{*}\right)$

2008

Page Numbers: $(*)$

511-515

Total Number of Pages (*)

5

ISBN No:

ISSN No:

D.O.I. (Digital Object Identifier): (*)

It doessn't appear to have one

Authors: (*)

Gilbert Shama and Gerben van der Els

(* denotes field must be completed) 
A Whirlwind in Occupied Holland

RAF leaflet informed and encouraged Dutch microbiologists who sought to produce antibiotics during World War II

Gilbert Shama and Gerben van der Els

Gilbert Shama is a Senior Lecturer in the Department of Chemical Engineering at Loughborough University in the United Kingdom and Gerben van der Els is a Nurse Anesthesist at the Sint Anna Hospital, Geldrop, the Netherlands.

Summary

- Two separate groups of Dutch microbiologists led clandestine efforts to produce antibiotics while the country was occupied during World War II.

- In one of these efforts, J.V. Köningsberger and Abraham van Luyk at the Botanical Laboratory in Utrecht tested antibiotics produced by Penicillium expansum on animals and humans.

- Although hampered by wartime censorship, this Dutch group benefitted from information on penicillin from an unusual source - namely, a leaflet that British Royal Air Force (RAF) fliers dropped over Holland.

- The group in Utrecht laboured under conditions of severe deprivation, but despite their best efforts their work came to an abrupt end in August 1944 when gas and electricity supplies collapsed.

Penicillin underwent a transformation from laboratory curiosity to the first massproduced antibacterial chemotherapeutic agent during the Second World War. Popular accounts of this process, particularly those that appeared immediately after the war have tended to cast events as a continuous series of related breakthroughs.

Even allowing for the various elisions that make for a good story, the ultimate success of the Anglo-American effort can not be denied.

\section{European Efforts To Make Antibiotics in Mass Quantities}

Few writers have drawn attention to the fact that this was not the only such attempt to produce antibiotics during the war. In reality, there were several independent attempts in Europe to produce penicillin and other antibiotics during World War II. Although none of these was ever to make a significant clinical impact, they reveal something of the human capacity for resourcefulness in straitened circumstances and at a time when the normal channels of scientific exchange of information had been severed. This account concerns one such attempt that took place in Holland.

One of these efforts involved a group working at the Nederlandsche Gist-en Spiritusfabriek in Delft (ASM News, January 2003, p. 25). Meanwhile, there was at 
least one other attempt to produce antibiotics in Holland during the same period, according to intelligence reports that were compiled following liberation of Holland in May 1945. Those reports are based mainly on testimony presented to British and American technical specialists, who followed advancing Allied armies. Their duties included uncovering scientific activities that had taken place in occupied countries throughout Europe as well as in Germany.

Among those interviewed - by three separate teams of Allied specialists - was J.V. Köningsberger, then a professor at the Botanical Laboratory in Utrecht. He began by refering to his coworker Abraham van Luyk, who earlier had worked at the Willie Commelin Scholten School of Phytopathology (WCS) in Baarn, near Utrecht, before joining Köningsberger early in 1940.

In 1932 while at WCS, van Luyk began investigating the infection of grasses by the fungal parasite Pythium debaryanum. Those experiments rapidly led to his study of antagonistic interactions between different fungi. He isolated a strain of Pullaria pullulans that could inhibit $P$. debaryanum by producing a supposed antibiotic and, separately, stimulate the growth of seedlings. Later, he isolated a number of penicillia, one of which, a strain of Penicillium expansum, was highly active against $P$. debaryanum. Interestingly, Köningsberger, stated that van Luyk was aware of Alexander Fleming's work with $P$. notatum.

According to one of the Allied intelligence reports, these "observations brought [van Luyk] to the hypothesis that the health of culture crops must be ascribed to the presence of antibiotically active microorganisms." Later, van Luyk realized that a similar concept might apply to animals and humans, forming the notion that resistance to, or tolerance of, various parasites is due to antibiotic-producing microorganisms in what he termed the "portae." He later explained that this term applied to the gastrointestinal tract, respiratory organs, and skin.

Van Luyk began testing antibiotics from the culture fluid of $P$. expansum firstly on animals and subsequently on humans. Such testing required him to cultivate these fungi on a large scale and to develop procedures for partly purifying the antibiotic. Because van Luyk was interested in antagonisms between molds, he began by testing culture fluids against fungal pathogens of the skin. For instance, the culture filtrates strongly inhibited Trichophyten resaseum, an organism that causes skin mycoses. Later, he tested the materials against pathogenic bacteria such as Staphylococcus aureus - although he does not seem to have extended his tests with either this or other bacteria to animals. Similarly, no direct reference is made in the intelligence reports to the efficacy of the filtrates on humans but it must be supposed that at least some beneficial results were achieved.

\section{Other Dutch Scientists Learned of van Luyk's Antibiotic Studies}

Accounts of van Luyk's efforts reached other Dutch scientists, including J. J.

Duyvene de Wit who was in charge of research at the pharmaceutical firm Brocades, Stheeman and Pharmacia, and it was De Wit who put van Luyk in contact with Köningsberger to continue working after he left WCS. De Wit also secured the cooperation of a B.C.P. Jansen at the Netherlands Institute of Nutrition in Amsterdam.

Van Luyk's work progressed more or less steadily throughout the early years of the war but was occasionally beset by difficulties that became apparent from inconsistent results in animal trials. One method of isolating the antibiotic, which the Dutch researchers termed "expansin," relied on activated carbon columns to which the 
material bound and was subsequently eluted. However, the researchers eventually realized that there were differences in recovery from one batch to another because [authors, OK?] their strains of $P$. expansum were degenerating following repeated subculturing. They solved this problem by periodically reisolating fresh strains from pieces of apple placed in contact with soil.

Since the occupation of Holland by German troops, the flow of scientific and technical journals and books had been abruptly halted. Starved for information, researchers in Utrecht devised their own ingenious assay procedures for expansin, using the fungus $P$. debaryanum as the target organism. They stepped up production of crude broth filtrates and at one stage they were growing the mold in large flasks in a heated room, generating about 80 gallons of crude broth each week.

\section{Air-Dropped Leaflet Helps To Spur Continued Penicillin Production Efforts}

What could have spurred the workers to continue production at this large scale? In one of the intelligence reports, Köningsberger mentions obtaining information on penicillin from an unusual source - namely, a leaflet that British Royal Air Force (RAF) fliers dropped over Holland. An enthusiastic collector of those wartime leaflets provided us with the text of one that is a strong contender for the one that Köningsberger mentions (Fig. 1). The leaflet was number 19 in the series known as "Wervelwind" or Whirlwind, it was released on the night of 24-25 April 1944 over a number of towns in Holland, with the nearest to Utrecht being Hilversum.

Presumably, someone in the drop zone who was aware of Köningsberger's interest in molds made sure it reached his hands.

The leaflet was not a guide for producing penicillin but rather a news story to boost morale in occupied Holland, whose citizens were starved for information other than that force fed to them by their occupiers. The leaflet describes penicillin as a new wonder drug. But how many times had that term been misapplied? During the occupation, Dutch citizens grew accustomed to crude propaganda, and leaflet writers surely realized that they needed to overcome war-induced skepticism.

Thus, the leaflet was cast in sober terms and began by providing a brief historical account of then-available chemotherapeutic antimicrobial agents that worked, starting with salvarsan, Paul Ehrlich's treatment for syphilis. The text also mentioned the sulfonomides, provided a conventional account of the discovery of penicillin by Fleming, and described the work undertaken by Florey and a "large group of chemists, bacteriologists, and physicians in England and America [who] are being put to work to unravel the secrets of the miracle product of a mold."

The leaflet included brief references as to how penicillin should be administered and the fact its production was being reserved for the military, with only small quantities being available for civilian use. The leaflet ends in suitably stirring terms likening penicillin to a new ally against germs - the "enemy." Almost as an afterthought, it included brief mention of another antimicrobial substance produced by fungi, namely patulin, or clavacin, that then was being used against influenza - and to which we shall return.

\section{Sporadic Access to Published Materials}

We do not mean to imply that Köningsberger and van Luyk believed that they were working with penicillin. As has already been stated, Van Luyk knew about Fleming's 
work even before Howard Florey revived interest in penicillin in 1940. Moreover, Shteeman of the firm Brocades, Shteeman and Pharmacia was trying to produce penicillin at the Gist plant in Delt and likely knew about what van Luyk was doing in Utrecht from Duyvene de Wit. Rather, the news that penicillin-a different antibiotic - was showing such promise and was the focus of a massive Allied development program would certainly have spurred the workers in Utrecht.

The leaflet dropped by the RAF was not the sole source of information on penicillin from the outside world for Köningsberger. He also revealed that that he had read about penicillin in a Swiss medical journal, and information from that report article was reproduced in one of the Allied intelligence reports. The journal article appears to have included a survey of secondary metabolites of the penicillia and probably drew on the studies of Harold Raistrick of the London School of Hygiene and Tropical Medicine. It also included what was an erroneous chemical formula for penicillin -this was possibly the one that Heilbron and his coworkers published in 1942 before an embargo on publishing structural details of penicillin was enforced. Such was the sensitivity relating to the structure of penicillin that the intelligence officials who interviewed Köningsberger were careful not to reveal the true structure to Köningsberger even though they regarded him as an ally.

Meanwhile, the technical teams interviewing the Dutch workers concluded that what the Dutch had all along been referring to as"expansin" probably was patulin. The Whirlwind leaflet included the information that patulin was being investigated in Britain as a cure for influenza, and the circumstances of how it came to be implicated in this role are curious to say the least. W. E. Gye, Director of the Imperial Cancer Research Fund, had undertaken to investigate patulin for its possible anticancer properties but happened to be suffering from influenza when he received a quantity of the compound from Raistrick.

Bizarrely, and on his own initiative, Gye bathed his nasal passages with a solution of the compound and rapidly recovered from his bout ofinfluenza. Greatly impressed with that result, Gye used his influential position to ensure that patulin was tested through a well-executed clinical trial.

Gye's action in dousing himself with patulin appears to owe something to van Luyks concepts of antibiotic producers standing as "sentinels at the portae" and it must have appeared both surprising and gratifying to the Dutch workers to see their own notions about infection apparently vindicated. One of the intelligence reports summarizes van Luyk's thinking on this issue: "Fungus is being isolated from oral flora in the hope of substantiating the theory advanced by personel to be mentioned [van Luyk and Köningsberger] that head colds and upper respiratory infections are associated with the status or activity of the fungus of the mouth and upper respiratory passages." Ultimately, the British trial showed definitively that patulin was ineffective as a treatment for influenza. And in fact much later patulin came to be classified as a mycotoxin and a carcinogen. Nowadays apple juice is routinely assayed for its presence as a contaminant.

\section{Wartime Dutch Antibiotics Researchers Faced other Hardships}

In Utrecht, the Dutch research group faced new challenges when gas and electricity supplies became unreliable, making it impossible for them to cultivate $P$. expansum as they had done before. However, they were undaunted, and sought to isolate new strains of $P$. expansum that could grow at lower temperatures. Even so, they faced shortages of other basic commodities, including methylated spirits needed to fuel their 
lab bench burners and even the matches with which to light them. Their refusal to accept defeat, while admirable, did not enable them to withstand the rapidly deteriorating circumstances surrounding them. Thus, it was in August 1944 that their work was brought to an abrupt end when gas and electricity supplies failed entirely.

Well before the Dutch group was forced to quit because basic supplies were lacking, they also faced drastic information shortages because of the dismal state of communications, according to the Allied investigators, who first met with the Dutch scientists on 26 May 1945. "The complete paralysis of all communications in Holland has to be experienced before it can be appreciated," the Allied intelligence officers wrote. "There are no trains, no buses, no trams, no postal service, into or in Holland ... Professor Köningsberger in Utrecht cannot keep in touch with Professor Jansen in Amsterdam. There are many bicycles but most have to be ridden without tyres. Wood blocks have been removed from roads for fuel. Utrecht has no gas or electricity and a reasonable water supply has only just been achieved."

Added to these hardships the Dutch researchers faced the constant threat of having their clandestine activities uncovered by the occupying forces. Thus, the efforts of the Dutch researchers in pursuit of antimicrobials was nothing short of heroic, and their efforts were recognized and praised by the Allied technical teams. One of them included the following personal note in his report: "The investigator takes the view that these Dutch scientific men have performed a valuable service to their country (and therefore to the Allies as a whole) by maintaining some kind of continuity of work and preserving their integrity." There can be no more fitting epitaph.

\section{ACKNOWLEDGMENTS}

The authors thank Hans Moonen for putting them in touch with each other, for providing images of leaflets dropped by the RAF, and for granting permission to publish them. Mr Moonen promotes interest in the psychological aspects of war on his website: ww2propaganda@home.nl

\section{SUGGESTED READING}

Bennett, J. W., and M. Klich. 2003. Mycotoxins. Clin. Microbiol. Rev. 16: 497-516.

Burns, M., and J. W. Bennett. 2003. Code name Bacinol. ASM News 69:25-31.

Clarke, M. 2006. The 1944 patulin trial of the British Medical Research Council. J. Roy. Soc. Med. 99:478-480.

Macfarlane, G. 1985. Alexander Fleming, the man and the myth. Oxford University Press, Oxford.

Schippers, B., and G. S. Roosje. 1997. Hundred years of history and the future of the Foundation' Willie Commelin Scholten Phytopathological Laboratory.' Eur. J. Plant Pathol. 103:667-671.

Shama, G., and J. Reinarz. 2002. Allied intelligence reports on wartime German penicillin research and production. His. Stud. Phys. Biol. Sci. 32:347-367. 